\title{
Two Novel Dicoumaro-p-menthanes from Gerbera piloselloides (L.) Cass.
}

\author{
Ying XIAO, ${ }^{a}$ Yi Ding, ${ }^{*}, b$ Jian-Bei LI, ${ }^{a}$ Yang Lu, ${ }^{a}$ and Toshihiro NOHARA ${ }^{c}$ \\ ${ }^{a}$ Institute of Materia Medica, Chinese Academy of Medical Sciences; Beijing 100050, China: ${ }^{b}$ Department of Biological \\ Sciences \& Biotechnology, Tsinghua University; Beijing 100084, China: and ${ }^{c}$ Faculty of Medical and Pharmaceutical \\ Sciences, Kumamoto University; 5-1 Oe-honmachi, Kumamoto 862-0973, Japan. \\ Received May 10, 2004; accepted August 2, 2004
}

Two new type dicoumarins (dicoumaro-p-menthanes), named dibothrioclinins I (1) and II (2) were isolated from the roots and rhizomes of Gerbera piloselloides (L.) CAss., collected in Yunnan Province, China. Their structures were elucidated on the basis of MS, $1 \mathrm{D}\left({ }^{1} \mathrm{H}-\mathrm{NMR},{ }^{13} \mathrm{C}-\mathrm{NMR}\right.$, DEPT and NOE) and $2 \mathrm{D}\left({ }^{1} \mathrm{H}-{ }^{1} \mathrm{H}\right.$ COSY, HMQC, HMBC) NMR spectral analyses. The relative structures of the two compounds were established by NOE difference spectroscopy and further confirmed by single-crystal X-ray diffraction studies.

Key words Gerbera piloselloides; dicoumarin; dicoumaro-p-menthane

In order to identify the active principles from the plant and develop and utilize the resources of Chinese medicine in minority area, the study of the chemical constituents of Gerbera piloselloides (L.) CAss. was carried out. Gerbera piloselloides is a plant of the Gerbera genus belonging to Compositae, collected at Yunnan Province. Gerbera piloselloides has been used as an antipyretic, alexipharmic, and for regulating the flow of vital energy and blood condition in traditional Chinese medicine. ${ }^{1)}$ From the alcoholic extracts of the roots and rhizome of Gerbera piloselloides, 15 known compounds $^{2,3)}$ and two new type dicoumarins (dicoumaro- $p$ menthanes) $(\mathbf{1}, 2)$ were isolated. This paper deals with the structure elucidation of two new compounds named dibothrioclinins I (1) and II (2).

Dibothrioclinin I (1) was obtained as a colorless block crystal with the molecular formula $\mathrm{C}_{30} \mathrm{H}_{28} \mathrm{O}_{6}$ determined by HR-EI-MS at $\mathrm{m} / z$ 484.191078 [M] ${ }^{+}$, indicating 17 unsaturation in the molecule. The IR absorption at $1227,1701 \mathrm{~cm}^{-1}$ ( $\alpha, \beta$-unsaturated lactone) and 1566,1599 , and $1614 \mathrm{~cm}^{-1}$ (aromatic $\mathrm{C}=\mathrm{C}$ ), along with $\mathrm{UV}$ absorption at $\lambda_{\max } 282$ ( $\log \varepsilon$ 4.35), 292 (4.37), and 307 (4.20) nm indicated that compound 1 possessed a coumarin skeleton. ${ }^{4)}$ In the ${ }^{1} \mathrm{H}-\mathrm{NMR}$ spectrum (Table 1) of $\mathbf{1}$, the absence of a pair of doublets at $\delta$ around $6.0-8.0$ indicated that the coumarin should be substituted at $\mathrm{C}-3^{\prime}$ and $\mathrm{C}-4^{\prime}$. The ${ }^{13} \mathrm{C}-\mathrm{NMR}$ spectrum (Table 2) of 1 showed 30 carbon signals, which included 18 carbons due to coumarin skeletons and 12 other carbons attributed to five methyls $\left(\delta_{\mathrm{C}} 23.7,23.9,25.1,28.5,29.1\right)$, two methylenes $\left(\delta_{\mathrm{C}} 31.5,39.4\right)$, three methines $\left(\delta_{\mathrm{C}} 25.9\right.$, $27.4,43.1)$ and two quaternarys $\left(\delta_{\mathrm{C}} 78.7,81.3\right)$. The signals due to two groups of aromatic protons at $\delta_{\mathrm{H}} 7.00$ (d, $J=7.5 \mathrm{~Hz}$ ), 7.05 (d, $J=7.5 \mathrm{~Hz}), 7.14$ (d, $J=8.0 \mathrm{~Hz}), 7.14$ $(\mathrm{d}, J=8.0 \mathrm{~Hz}), 7.32(\mathrm{dd}, J=7.5,8.0 \mathrm{~Hz})$ and $7.35(\mathrm{dd}, J=7.5$, $8.0 \mathrm{~Hz}$ ) of 1 in the ${ }^{1} \mathrm{H}-\mathrm{NMR}$ spectrum indicated that $\mathbf{1}$ had two phenyl units with an $\mathrm{ABC}$ or $\mathrm{ABX}$ substitution system. Therefore, compound 1 probably contained two resembling coumarin units, which were linked into a dimer.

The correlations of two methylene protons and three aliphatic methine protons (H-6 and H-5, H-5 and H-4, H-4 and $\mathrm{H}-3, \mathrm{H}-3$ and $\mathrm{H}-2$ ) in the ${ }^{1} \mathrm{H}-{ }^{1} \mathrm{H}$ COSY spectrum indicated that $\mathrm{C}-2,3,4,5,6$ should be linked one by one to form a new ring. In the HMBC spectrum (Table 1), the correlations between the methyl protons $\mathrm{H}-11^{\prime}\left(\delta_{\mathrm{H}} 2.70\right)$ and the aromatic carbon $\mathrm{C}-5^{\prime}\left(\delta_{\mathrm{C}} 136.9\right), \mathrm{C}-6^{\prime}\left(\delta_{\mathrm{C}} 127.5\right)$ and C-10' $\left(\delta_{\mathrm{C}} 114.5\right)$ showed that the methyl group $\left(\mathrm{C}-11^{\prime}\right)$ was located at $\mathrm{C}-5^{\prime}$ of one coumarin. Similarly, the methyl group at C-11"

Table 1. ${ }^{1} \mathrm{H}-\mathrm{NMR}$ Data for Compounds 1 and 2 in $\mathrm{CDCl}_{3}(500 \mathrm{MHz}, \delta$ in ppm, $J$ in $\mathrm{Hz}$ )

\begin{tabular}{|c|c|c|c|c|}
\hline Position & 1 & $\operatorname{HMBC}\left({ }^{1} \mathrm{H}\right.$ to $\left.{ }^{13} \mathrm{C}\right)$ & 2 & $\mathrm{HMBC}\left({ }^{1} \mathrm{H}\right.$ to $\left.{ }^{13} \mathrm{C}\right)$ \\
\hline $6^{\prime}$ & $7.00(\mathrm{~d}, 7.5)$ & $\mathrm{C}-5^{\prime}, 7^{\prime}, 8^{\prime}, 10^{\prime}, 11^{\prime}$ & $6.81(\mathrm{~d}, 8.0)$ & $\mathrm{C}-5^{\prime}, 7^{\prime}, 8^{\prime}, 10^{\prime}, 11^{\prime}$ \\
\hline $7^{\prime}$ & $7.32(\mathrm{dd}, 7.5,8.0)$ & $\mathrm{C}-5^{\prime}, 6^{\prime}, 9^{\prime}$ & $7.31(\mathrm{t}, 8.0)$ & $\mathrm{C}-5^{\prime}, 6^{\prime}, 8^{\prime}, 9^{\prime}$ \\
\hline $8^{\prime}$ & $7.14(\mathrm{~d}, 8.0)$ & $\mathrm{C}-6^{\prime}, 9^{\prime}, 10^{\prime}$ & $7.12(\mathrm{~d}, 8.0)$ & $\mathrm{C}-6^{\prime}, 9^{\prime}, 10^{\prime}$ \\
\hline $6^{\prime \prime}$ & $7.05(\mathrm{~d}, 7.5)$ & $\mathrm{C}-5^{\prime \prime}, 7^{\prime \prime}, 8^{\prime \prime}, 10^{\prime \prime}, 11^{\prime \prime}$ & $7.00(\mathrm{~d}, 7.5)$ & $\mathrm{C}-5^{\prime \prime}, 7^{\prime \prime}, 8^{\prime \prime}, 10^{\prime \prime}, 11^{\prime \prime}$ \\
\hline $7^{\prime \prime}$ & $7.35(\mathrm{dd}, 7.5,8.0)$ & $\mathrm{C}-5^{\prime \prime}, 6^{\prime \prime}, 9^{\prime \prime}$ & $7.31(\mathrm{t}, 7.5)$ & $\mathrm{C}-5^{\prime \prime}, 6^{\prime \prime}, 8^{\prime \prime}, 9^{\prime \prime}$ \\
\hline $8^{\prime \prime}$ & $7.14(\mathrm{~d}, 8.0)$ & $\mathrm{C}-6^{\prime \prime}, 9^{\prime \prime}, 10^{\prime \prime}$ & $7.14(\mathrm{~d}, 7.5)$ & $\mathrm{C}-6^{\prime \prime}, 9^{\prime \prime}, 10^{\prime \prime}$ \\
\hline $2 \mathrm{a}$ & $1.77(\mathrm{~d}, 13.5)$ & $\mathrm{C}-1,4,7$ & $1.52(\mathrm{dd}, 3.6,13.8)$ & $C-1,4,5,7,6$ \\
\hline $2 b$ & $2.17(\mathrm{dd}, 13.5,2.5)$ & $\mathrm{C}-3^{\prime \prime}, 3$ & $2.13(\mathrm{dd}, 3.6,13.8)$ & $\mathrm{C}-3^{\prime \prime}, 3$ \\
\hline 3 & $3.53(\mathrm{~d}, 2.5)$ & $\mathrm{C}-2^{\prime \prime}, 3^{\prime \prime}, 4^{\prime \prime}, 1,4,5$ & $3.11(\mathrm{~m})$ & $\mathrm{C}-2^{\prime \prime}, 3^{\prime \prime}, 1,4$ \\
\hline 4 & $2.23(\mathrm{~d}, 7.0)$ & $\mathrm{C}-3^{\prime}, 2,3,5,6,8,9,10$ & $1.60(\mathrm{dd}, 6.0,2.5)$ & $\mathrm{C}-3^{\prime}, 3^{\prime \prime}, 3,8,9,10$ \\
\hline 5 & $2.98(\mathrm{~m})$ & $\mathrm{C}-2^{\prime}, 3^{\prime}, 4^{\prime}, 4,6,8$ & $2.56(\mathrm{ddd}, 12.0,6.0,4.5)$ & $\mathrm{C}-3^{\prime}, 4^{\prime}, 1,4,6,8$ \\
\hline $6 a$ & $1.66(\mathrm{dd}, 13.5,4.5)$ & $\mathrm{C}-3^{\prime}, 2,5,7$ & $1.57(\mathrm{dd}, 15.0,12.0)$ & $\mathrm{C}-3^{\prime}, 1,4,5,8$ \\
\hline $6 b$ & $3.12(\mathrm{dd}, 13.5,5.5)$ & $\mathrm{C}-1,2,4,5$ & $3.70(\mathrm{dd}, 15.0,4.5)$ & $\mathrm{C}-3^{\prime}, 1,4,5,7,8$ \\
\hline 7 & $1.58(\mathrm{~s})$ & $C-1,2,6$ & $1.74(\mathrm{~s})$ & C-4", $1,2,6$ \\
\hline 9 & $1.85(\mathrm{~s})$ & $\mathrm{C}-4,8,10$ & $1.86(\mathrm{~s})$ & $\mathrm{C}-4^{\prime}, 4,8,10$ \\
\hline 10 & $1.58(\mathrm{~s})$ & $\mathrm{C}-4,8,9$ & $1.36(\mathrm{~s})$ & $\mathrm{C}-4,8,9$ \\
\hline $11^{\prime}$ & $2.70(\mathrm{~s})$ & $C-5^{\prime}, 6^{\prime}, 10^{\prime}$ & $2.60(\mathrm{~s})$ & $\mathrm{C}-5^{\prime}, 6^{\prime}, 9^{\prime}, 10^{\prime}$ \\
\hline $11^{\prime \prime}$ & $2.77(\mathrm{~s})$ & $\mathrm{C}-5^{\prime \prime}, 6^{\prime \prime}, 10^{\prime \prime}$ & $2.64(\mathrm{~s})$ & $\mathrm{C}-5^{\prime \prime}, 6^{\prime \prime}, 9^{\prime \prime}, 10^{\prime \prime}$ \\
\hline
\end{tabular}


Table 2. ${ }^{13} \mathrm{C}$-NMR Data for Compounds $\mathbf{1}$ and $\mathbf{2}$ in $\mathrm{CDCl}_{3}(75 \mathrm{MHz}, \delta$ in ppm)

\begin{tabular}{|c|c|c|c|c|c|}
\hline $\mathrm{C}$ & 1 & 2 & $\mathrm{C}$ & 1 & 2 \\
\hline $2^{\prime}$ & $161.5(\mathrm{~s})$ & $161.6(\mathrm{~s})$ & $2^{\prime \prime}$ & $161.7(\mathrm{~s})$ & $161.6(\mathrm{~s})$ \\
\hline $3^{\prime}$ & $102.0(\mathrm{~s})$ & $101.7(\mathrm{~s})$ & $3^{\prime \prime}$ & $103.6(\mathrm{~s})$ & $108.5(\mathrm{~s})$ \\
\hline $4^{\prime}$ & $162.1(\mathrm{~s})$ & $162.7(\mathrm{~s})$ & $4^{\prime \prime}$ & $164.3(\mathrm{~s})$ & $161.8(\mathrm{~s})$ \\
\hline $5^{\prime}$ & $136.9(\mathrm{~s})$ & $137.1(\mathrm{~s})$ & $5^{\prime \prime}$ & $137.1(\mathrm{~s})$ & $137.0(\mathrm{~s})$ \\
\hline $6^{\prime}$ & $127.5(\mathrm{~d})$ & $127.6(\mathrm{~d})$ & $6^{\prime \prime}$ & $127.5(\mathrm{~d})$ & $127.6(\mathrm{~d})$ \\
\hline $7^{\prime}$ & 130.9 (d) & $131.0(\mathrm{~d})$ & $7^{\prime \prime}$ & 130.7 (d) & 131.0 (d) \\
\hline $8^{\prime}$ & 115.1 (d) & $115.1(\mathrm{~d})$ & $8^{\prime \prime}$ & 115.0 (d) & $115.3(\mathrm{~d})$ \\
\hline $9^{\prime}$ & $153.7(\mathrm{~s})$ & $154.2(\mathrm{~s})$ & $9^{\prime \prime}$ & $154.0(\mathrm{~s})$ & $154.1(\mathrm{~s})$ \\
\hline $10^{\prime}$ & $114.5(\mathrm{~s})$ & $115.0(\mathrm{~s})$ & $10^{\prime \prime}$ & $114.2(\mathrm{~s})$ & $114.8(\mathrm{~s})$ \\
\hline 1 & $78.7(\mathrm{~s})$ & $80.4(\mathrm{~s})$ & 7 & $28.5(q)$ & $29.6(q)$ \\
\hline 2 & $31.5(\mathrm{t})$ & $30.5(\mathrm{t})$ & 8 & $81.3(\mathrm{~s})$ & $83.3(\mathrm{~s})$ \\
\hline 3 & $27.4(d)$ & $25.3(\mathrm{~d})$ & 9 & $29.1(q)$ & $28.5(q)$ \\
\hline 4 & 43.1 (d) & $52.0(\mathrm{~d})$ & 10 & $25.1(\mathrm{q})$ & $21.1(q)$ \\
\hline 5 & 25.9 (d) & $25.6(d)$ & $11^{\prime}$ & $23.9(q)$ & $23.9(\mathrm{q})$ \\
\hline 6 & $39.4(\mathrm{t})$ & $40.5(\mathrm{t})$ & $11^{\prime \prime}$ & $23.7(q)$ & $23.7(q)$ \\
\hline
\end{tabular}

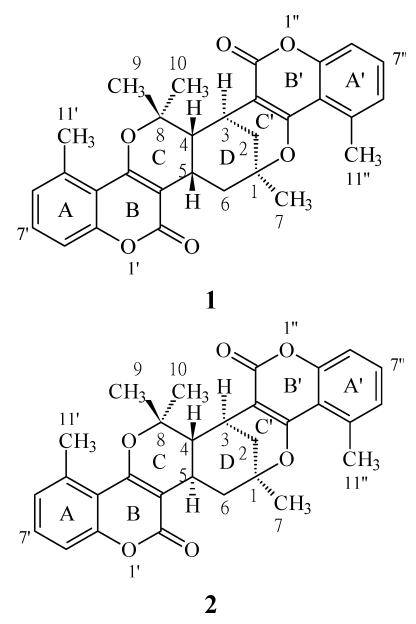

Fig. 1. Structures of Dibothrioclinins I (1) and II (2)

was located at C-5" of another coumarin. Two methyl groups at C-8 $\left(\delta_{\mathrm{H}} 1.85,1.58\right)$ were also correlated with carbon signals of C-8 $\left(\delta_{\mathrm{C}} 81.3\right)$ as well as C-4 $\left(\delta_{\mathrm{C}} 43.1\right)$, respectively. The correlations were also observed between the methyl group at $\mathrm{C}-1 \quad\left(\delta_{\mathrm{H}} 1.58\right)$ and carbon signal of $\mathrm{C}-1$ $\left(\delta_{\mathrm{C}} 78.7\right)$, as well as $\mathrm{C}-2$ and $\mathrm{C}-6$ at 31.5 and 39.4 , respectively. The methine protons of H-5 $\left(\delta_{\mathrm{H}} 2.98\right)$ and H-3 $\left(\delta_{\mathrm{H}}\right.$ 3.53) were respectively correlated with the two groups of quaternary carbons, one was $\mathrm{C}-2^{\prime}, \mathrm{C}-3^{\prime}$ and $\mathrm{C}-4^{\prime}$ and the other was C-2", C-3" and C-4". Thus, the HMBC correlations fixed the linkage of the D ring, in which C-2, 3, 4, 5, 6, together with $\mathrm{C}-1$ (carbon bearing oxygen) were linked to form a dimer of coumarin. At the same time, comparing the NMR data of 1 with that of bothrioclinin,, ${ }^{5)}$ a known coumarin, showed that they had identical NMR data due to ring $\mathrm{A}, \mathrm{A}^{\prime}$, $\mathrm{B}, \mathrm{B}^{\prime}, \mathrm{C}, \mathrm{C}^{\prime}$. Therefore, 1 should be a dimer of bothrioclinin. Obviously, D ring of $\mathbf{1}$ was in fact a $p$-menthane, that is, $\mathbf{1}$ was dicoumaro- $p$-menthane. So far, many dicoumarins ${ }^{6-11)}$ have been isolated from plants, but the structure of $\mathbf{1}$ is different from other known dicoumarins in dimerized manner. All signals in the ${ }^{1} \mathrm{H}$ - and ${ }^{13} \mathrm{C}$-NMR spectrum are assigned according to the HMQC, HMBC, ${ }^{1} \mathrm{H}-{ }^{1} \mathrm{H}$ COSY and DEPT. The assignments were shown in Tables 1 and 2 .

The relative stereochemistry of $\mathrm{H}-4, \mathrm{H}-5$ and $\mathrm{H}-3$ was deduced by the NOE difference spectroscopy. Irradiation of

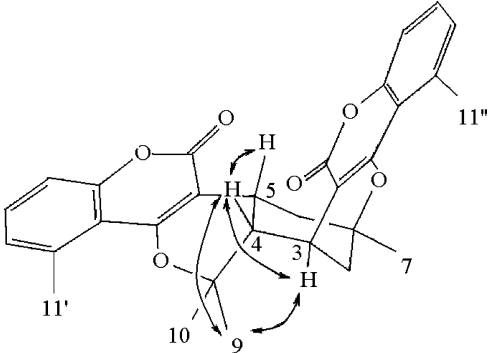

1

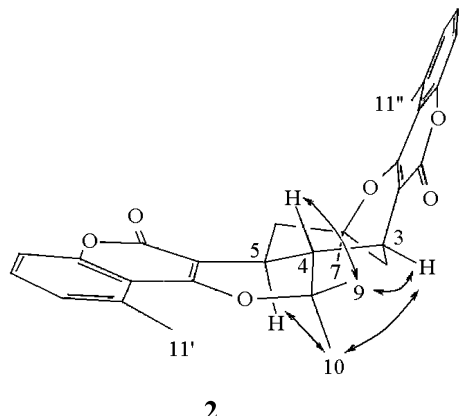

Fig. 2. Significant NOE Correlations of Dibothrioclinins I (1) and II (2)

the H-4 $\left(\delta_{\mathrm{H}} 2.23\right)$ resulted in a significant NOE of $\mathrm{H}-5$ $\left(\delta_{\mathrm{H}} 2.98\right)$, but NOE of H-5 was not observed when $\mathrm{H}-3$ was irradiated [Fig. 2, (1)]. Therefore, H-4 and H-5 should be located at the same side of the plane of the $\mathrm{D}$ ring, that is, H-4 and H-5 were cis-oriented, but H-3 and H-5 are transoriented. The relative structure of 1 was further confirmed by single-crystal X-ray diffraction studies [Fig. 3, (1)]. On the basis of the above analyses, 1 was elucidated to be a dicoumaro- $p$-menthane, named dibothrioclinin I.

Dibothrioclinin II (2) was obtained as a colorless plate crystal, which gave an molecular ion peak at $\mathrm{m} / \mathrm{z} 484.193668$ by a HR-EI-MS, indicating the molecular formula $\mathrm{C}_{30} \mathrm{H}_{28} \mathrm{O}_{6}$. Comparisons of the UV, IR, ${ }^{1} \mathrm{H}$ - and ${ }^{13} \mathrm{C}-\mathrm{NMR}$ spectra of 2 with those of 1 indicated that their structures were similar to each other. The major difference was the relative configuration of H-4, H-5 and H-3 in the ring D. The significant NOE correlations [Fig. 2, (2)] were observed between $\mathrm{H}-4$ and H-9, H-3 and H-9 as well as H-5 and H-10, H-3 and H-10. 


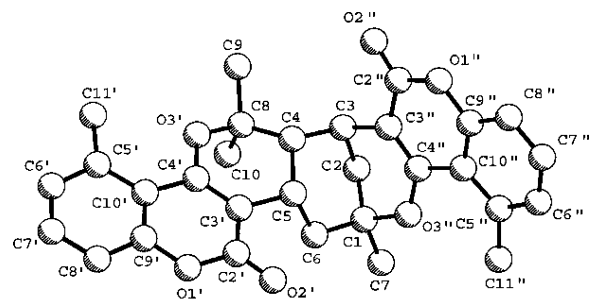

1

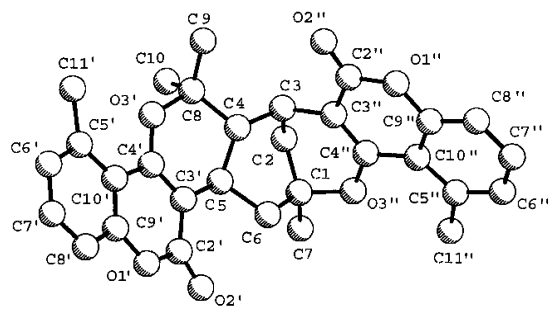

2

Fig. 3. Stereoviews of Dibothrioclinins I (1) and II (2) by X-Ray Crystallography

Finally, single-crystal X-ray diffraction analysis unambiguously confirmed the relative structure of $\mathbf{2}$ [Fig. 3, (2)]. Therefore, the structure of $\mathbf{2}$ was elucidated to be an isomer of $\mathbf{1}$, named dibothrioclinin II.

However, dibothrioclinin II (2) did not have optical activity unlike dibothrioclinin I (1). The single-crystal X-ray diffraction data indicated that it was a racemic mixture (space group $P 2 /$ a), including a pair of enantiomers.

\section{Experimental}

1D and 2D NMR spectra were recorded on a Mercury-300 spectrometer $(500 \mathrm{MHz})$. Chemical shift $(\delta)$ values were expressed in parts per million and were resonances at $\delta_{\mathrm{H}} / \delta_{\mathrm{C}} 7.26 / 77.0\left(\mathrm{CDCl}_{3}\right)$. EI-MS analyses were measured on a Zabspec Tofspec Platform-ESI. Optical rotations were measured on a Perkin-Elmer 241 polarimeter. IR spectra were recorded on an IMPACT 400 FT-IR spectrometer. UV spectra were scanned on a UV-260 spectrometer. Silica gel (200-300 mesh) for column chromatography was obtained from Qingdao Sea chemical plant and the HPLC column (YMCPack ODS-A, $250 \times 20 \mathrm{~mm}$ I.D., S-10P $\mu \mathrm{m}, 120 \AA$ ) was obtained from Japan.

Collection and Identification of Original Plant The roots and rhizomes of Gerbera piloselloides (L.) CAss. were collected from Dali, Yunnan Province in China and identified by Guang-ming Liu of Dali Medical College.

Extraction and Isolation The EtOH extract $(1.02 \mathrm{~kg})$ of roots and rhizomes $(10 \mathrm{~kg})$ of Gerbera piloselloides (L.) CAss. was partitioned between aqueous solution and petroleum ether. The petroleum ether fraction $(86.4 \mathrm{~g})$ was separated by silica gel chromatography eluted with pet-Et ${ }_{2} \mathrm{O} / \mathrm{EtOAc}(9: 1)$ to give colorless crystals $(106 \mathrm{mg})$. Purification of the crystals was made by means of preparative HPLC (Shimadzu LC6A, column: YMC-Pack ODS-A, $250 \times 20 \mathrm{~mm}$ I.D., S-10P $\mu \mathrm{m}, 120 \AA$ ) afforded compounds $\mathbf{1}(12 \mathrm{mg})$ and $\mathbf{2}(59 \mathrm{mg})$.

Dibothrioclinin I (1) Colorless block crystals, $\mathrm{mp}>300^{\circ} \mathrm{C},[\alpha]_{\mathrm{D}}^{19}+24^{\circ}$ $\left(c=0.05, \mathrm{CHCl}_{3}\right) ; \mathrm{IR} v_{\max }: 1227,1566,1599,1614,1701 \mathrm{~cm}^{-1} ; \mathrm{UV}\left(\mathrm{CHCl}_{3}\right)$ $\lambda_{\max }(\log \varepsilon): 228$ (4.10), 240 (4.08), 282 (4.35), 292 (4.37), 307 (4.20) nm;
HR-EI-MS $m / z: 484.191078[\mathrm{M}]^{+}$(Calcd for $\mathrm{C}_{30} \mathrm{H}_{28} \mathrm{O}_{6} \quad 484.188589$ ). ${ }^{1} \mathrm{H}$ - and ${ }^{13} \mathrm{C}-\mathrm{NMR}$ data: see Tables 1 and 2.

Dibothrioclinin II (2) Colorless plate crystals, $\mathrm{mp}>300^{\circ} \mathrm{C},[\alpha]_{\mathrm{D}}^{19} 0^{\circ}$ $\left(c=0.045, \mathrm{CHCl}_{3}\right)$; IR $v_{\max }: 1244,1552,1599,1610,1709 \mathrm{~cm}^{-1}$; UV $\left(\mathrm{CHCl}_{3}\right) \lambda_{\max }(\log \varepsilon): 228$ (4.02), 240 (4.08), 284 (4.36), 293 (4.39) nm; HR-EI-MS $m / z$ : $484.193668[\mathrm{M}]^{+}$, (Calcd for $\mathrm{C}_{30} \mathrm{H}_{28} \mathrm{O}_{6}$ 484.188589). ${ }^{1} \mathrm{H}$ - and ${ }^{13} \mathrm{C}-\mathrm{NMR}$ data: see Tables 1 and 2.

Crystal Structure Determination. Dibothrioclinin I (1) A single crystal suitable for X-ray diffraction was obtained by layering a $\mathrm{MeOH} / \mathrm{CHCl}_{3}$ solution of 1 . MoK $\alpha(\lambda=0.70930 \AA)$. The reflection data were collected on a Mac Science DIP $2030 \mathrm{~K}$ imaging plate with monochromation to a maximum $2 \theta$ value of $50^{\circ}$ at $22^{\circ} \mathrm{C}$. Of the reflections that were collected, 2186 were unique. The structure was solved by direct methods SIR 92 and expanded using Fourier techniques. The non-hydrogen atoms were refined anisotropically. Hydrogen atoms were included but not refined. The final cycle of the full-matrix least squares refinement was based on 2170 observed reflections $\left(|F|^{2} \geq 8 \sigma|F|^{2}\right)$. The structure was finally refined to $R f=0.050\left(w=1 / \sigma|F|^{2}\right)$. The crystal data are: $a=11.0010(5), b=8.3070(2)$, $c=13.3320(6) \AA$ and $\beta=90.388(3)^{\circ}, V=1218.32(8) \AA^{3}$, space group $P 2_{1}$, $Z=2, D_{\mathrm{C}}=1.326 \mathrm{~g} / \mathrm{cm}^{3}$.

Dibothrioclinin II (2) A single crystal suitable for X-ray diffraction

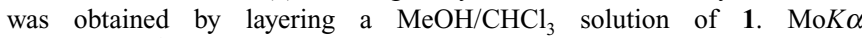
$(\lambda=0.70930 \AA)$. The reflection data were collected on a Mac Science DIP $2030 \mathrm{~K}$ imaging plate with monochromation to a maximum $2 \theta$ value of $50^{\circ}$ at $22^{\circ} \mathrm{C}$. Of the reflections that were collected, 3832 were unique. The structure was solved by direct methods SIR 92 and expanded using Fourier techniques. The non-hydrogen atoms were refined anisotropically. Hydrogen atoms were included but not refined. The final cycle of the full-matrix least squares refinement was based on 3810 observed reflections $\left(|F|^{2} \geq 8 \sigma|F|^{2}\right)$. The structure was finally refined to $R f=0.079, R_{\mathrm{w}}=0.069\left(w=1 / \sigma|F|^{2}\right)$. The crystal data are: $a=8.040(1), \quad b=19.532(1), \quad c=15.643(1) \AA$ and $\beta=77.081(1)^{\circ}, V=2393.2(4) \AA^{3}$, space group $P 2_{1} / \mathrm{a}, Z=4, D_{\mathrm{C}}=1.350 \mathrm{~g} / \mathrm{cm}^{3}$.

Atomic coordinates, bond lengths and angles and thermal parameters of both compounds have been deposited at the Crystallographic Diffraction Data Center of the Institute of Materia Medica, Chinese Academy of Medical Sciences, China.

Acknowledgements We are grateful to the Department of Instrumental Analysis of the Institute of Materia Medica, Chinese Academy of Medical Sciences and Peking Union Medical College for all spectra analyses. Dali Medical College is gratefully acknowledged for its assistance with sample collections.

\section{References and Notes}

1) Jiangsu New Medical College, "The Dictionary of Traditional Chinese Medicine," Previous volume, Science and Technology Publishing Company of Shanghai, Shanghai, 1977, p. 448.

2) Xiao Y., Li J.-B., Ding Y., Journal of Chinese Materia Medica, 27, 594-596 (2002).

3) Xiao Y., Li J.-B., Ding Y., Chinese Traditional and Herbal Drugs, 34, 109-111 (2003).

4) Gu L.-H., Wang S.-X., Li X., Zhou T. R., Acta Pharmaceutica Sinica, 22, 272-277 (1987)

5) Bohlmann F., Zdero C., Phytochemistry, 16, 1261-1264 (1977).

6) Chakraborty D. P., Shyamali R., Chakraborty A., Mandal A. K, Chowdhury B. K., Tetrahedron, 36, 3563-3564 (1980).

7) Basa S. C., Das D. P., Tripathy R. N., Elango V., Shamma M., Heterocycles, 22, 333-337 (1984).

8) Arisawa M., Kinghorn A. D., Cordell G. A., Farnsworth N. R., J. Nat. Prod., 47, 106-112 (1984).

9) Nozawa K., Seyea H., Nakajima S., Udagawa S., Kawai K., J. Chem. Soc., Perkin Trans. 1, 1987, 1735-1738 (1987).

10) Bhandari P., Rastogi R. P., Phytochemistry, 20, 2044-2047 (1981).

11) Saigo K., Yonezawa N., Sekimoto K., Hasegawa M., Ueno K., Nakanishi H., Bull. Chem. Soc. Jpn., 58, 1000-1005 (1985). 